\title{
Growing Up as "Man of the House": Adultification and Transition Into Adulthood for Young Men in Economically Disadvantaged Families
}

Kevin Roy, Lauren Messina, Jocelyn Smith, Damian Waters

\begin{abstract}
Many children in economically disadvantaged communities assume adult roles in their families. Negotiating the responsibilities and expectations associated with becoming what some young men describe as "man of the house" has important implications for how adolescent boys move into adulthood. In this study, we share insights from field work and life-history interviews with lowincome, young African American men and Salvadoran men in the Washington, DC/Baltimore region to illustrate how adultification may deliver contradictory expectations for adolescents. The findings also show how the accelerated responsibilities that accompany the experience of adultification create difficulties in the young men's transition into adulthood. These findings indicate that the age period of emerging adulthood may begin earlier for economically disadvantaged young men. (c) 2014 Wiley Periodicals, Inc.
\end{abstract}


[So what was your role in the family when you were in high school?] Man of the house. [What does that mean? What do you have to do as man of the house?] You know, I still had to ... go around the house and clean up, had to give up my room for my sister and the baby, and we only had two rooms in the apartment, had to give up my room.... A man of the house needs to do this, be caretaker, protector. Sylvester, 18

I was basically trying to be a man before I had to. Fry, 19

I was living like an adult as a kid. Matt, 20

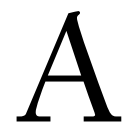

t young ages, many children accept advanced responsibilities of provision and care for their family members, including mothers, siblings, cousins, and grandparents. Such adultification involves acquiring precocious knowledge as well as acting as peer, spouse, or even parent for one's own parents (Burton, 2007). Family transitions and movement into early adult roles (such as marriage, parenthood, or independent living) lead toward enhanced perceptions of adulthood (Johnson \& Mollborn, 2009; Shanahan, Porfeli, Mortimer, \& Erickson, 2005). Moreover, stress experienced through physical abuse, exposure to violence, and living in unsafe neighborhoods may result in perceptions of being older than one's age peers.

Foster, Hagan, \& Brooks-Gunn (2008) examined Add Health data on young adult women and identified processes of subjective weathering, a social psychological dimension of adultification that develops alongside physical weathering related to accelerated aging due to stress (Geronimus, 1992, 2001). Few studies have examined similar processes of adultification for young men in economically disadvantaged households. Men of color face a distinct set of challenges in navigating risks in their families and communities that require them to confront institutional power, violence and trauma, and complex relationships with adults (Harding, 2010; Rich, 2009). Yet, we lack in-depth consideration of the contexts and meanings of their pathways from boyhood to adolescence and through to young adulthood.

Ethnographic and other qualitative studies provide some insight into family dynamics as young disadvantaged men age. Parents face difficult options in keeping their boys safe, monitoring their activities, and engaging them in school (Burton, Winn, Stevenson, \& McKinney, 2014). Teenage boys in economically disadvantaged households may provide critical caregiving support for their siblings or financial support for their parents (Roy, Dyson, \& Jackson, 2010; Roy \& Smith, 2012; Roy \& Vesely, 2009). Such experiences can socialize them to be involved fathers. In this way, men in disadvantaged families can play a role as kinkeepers, weaving together commitments from varied family members and promoting family legacies even as nonresidential or unmarried fathers (Burton \& Stack, 2014; Marsiglio \& Roy, 2012; Roy \& Burton, 2007). 
As Weiss (1979) noted, children in single-parent households in particular become partners in household management. Young disadvantaged men may often feel pressure to become, as one respondent describes above, "the man of the house" well before they reach their late teen years. They may seek to fill the void of an absent father who cannot play the role of man of the house. Even if they can help to manage households, care for siblings, or contribute money, boys and adolescents typically lack the authority to fulfill these adult expectations. They also receive few of the privileges afforded to parents and other adults, such as clear lines of authority, respect from other adults, or even routine privacy.

Understandings of what it means to be a man of the house reflect traditional expectations for men's patriarchal authority and responsibilities for financial provision, discipline, and decision making in family life (Coltrane, 1997; Thornton, Alwin, \& Camburn, 1983). Youth develop visions that are shaped by these understandings of traditional masculine roles. Family members may use the term to compel boys to help out with their families, but these expectations can be vague and open to interpretation. These problematic expectations can lead to contradictions that have important implications for later years. Perceptions and decisions about close relationships, identity formation as a self-sufficient adult, as well as one's place in a dynamic and limited world of jobs and careers may be shaped by how young men age out of their roles as men of the house and into their own unique adulthood (Way, 2011; Young, 2004).

Adultification may carry positive consequences that emerge in young adulthood as well, as Burton (2007) indicates that some adultification processes may unfold alongside mentors. Research on emerging adulthood suggests that young adults typically seek and receive support from their parents, such as financial resources (Mouw, 2005). Even ongoing relationships with parents can provide critical social capital for young adults (Furstenberg $\&$ Hughes, 1995). Close ties may be particularly helpful to young adults at specific turning points, such as when they become parents themselves. Social support from their own parents can help to buffer new fathers from risk and keep them engaged in school and work activities (Roy, Vesely, Fitzgerald, \& Buckmiller Jones, 2010).

In this study, we conducted field work and life-history interviews with low-income, young African American men and Salvadoran men in the Washington, DC/Baltimore region. Through interaction with them in community centers over many months, we explored the circumstances and contexts in which they become men of the house-or not-and how adultification may deliver contradictory sets of expectations for adolescents with few resources themselves. Most importantly, men reflected on how accelerated responsibilities and experiences shaped their own transition into a sense of adulthood. We consider conceptual contributions of these findings for our understanding of adultification and emerging adulthood for young 
economically disadvantaged men. Implications for policy and programs will also be discussed.

\section{Methods}

Our research team worked for 18 months in two youth development programs in the Baltimore/Washington, DC, metropolitan area. The UP program (Urban Progress) had been situated in the community for over a decade, helping out-of-school youth and young adults to "turn their lives around." This sprawling one-story brick facility sat underneath an expressway overpass and alongside strings of rowhouses that were home to generations of African American families in the local community. UP staff provided career guidance, literacy and GED, job readiness and placement, life skills and health education classes, as well as substance abuse counseling and extensive mental health interventions and counseling. Our research team, including students trained in couple and family therapy, facilitated two weekly life skills sessions in conflict management, coping with exposure to violence, and stress and depression. Initial facilitation over 12 months was extended for another 12 months by two researchers.

The second program, Diversity Matters, was also a youth development project. In contrast, this facility was located in a former high school, tucked into the back streets of a residential community of single-family homes. A community garden ran alongside the perimeter of the building, and the facility was shared with extension educators from the nearby university. Cohorts of Diversity Matters participants worked as mentors for high school students and congregated daily in the afternoon for career training, supervision, and life skills classes. Over six months of spring/summer training, and again over the same period one year later, our research team offered similar interactive sessions in the Diversity Matters facility.

Participants. The UP program classes consisted of young men and women, but given the focus of our project, we approached only young men in classes to ask if they would like to participate in an interview. Twenty-one African American men, between the ages of 18 and 24, agreed to participate. The majority of these participants had lived in the local urban community since birth, among generations of family members who had grown up there as well. All of the participants had dropped out of high school, and the promise of a GED was the most important draw to the program. About 20\% $(n=4)$ of the young men were fathers, and over half had some experience with incarceration in the state.

In contrast, of the 20 men recruited at the Diversity Matters site, five were African American, two were West African, and 13 were Salvadoran, which reflected the racial and ethnic variation in the program as a whole. They tended to be younger than the participants from the UP site (17-19 years) and in their first two years after high school graduation, another contrast to the UP participants. Most of these young men lived in immigrant 
families, as first- or second-generation immigrants, and were the first members of their families to aspire to go to college. As a group, their families were a mix of working-class and low-income households. None of them were young parents, and only a few were considered ex-offenders.

We planned to recruit two groups of young men with these subtle but important differences in educational attainment. Variation by age, race, and ethnicity was also important in understanding processes of adultification and parental support, and we hoped to capture different family household configurations as well. An emergent and unexpected theme was a consideration of being or becoming a man of the house, and as a result, we purposively sought to speak with young men who had this experience as adolescents or boys. When we reached close to 20 participants in each site, we realized that we had multiple cases of being a man of the house, as well as rich variation in the meaning and circumstances behind this status. There were also many cases in which young men were not expected to jump into accelerated adult roles, and these young men provide a helpful contrast group.

Data Collection. We used two primary methods of data collection. For many weeks, the research team took extensive field notes on formal session interactions as well as informal and extended conversations with staff and participants in each site. This method provided information on ecological processes and contexts (such as negotiation of neighborhoods and peer networks, limited job and educational opportunities, and physical mobility), community barriers and supports for youth development, mental health considerations (especially from the UP site), and close relationships with friends and family members. After we developed a consistent and trusting relationship with the participants, we mentioned to each of the young men in class that we would like to arrange an interview with them. We worked to approach each class member, but those who did not attend regularly were less likely to be approached multiple times for an interview. They also were less likely to confirm and meet for an interview, even after initial agreement.

We met young men in a separate, private classroom in each site to conduct a one- to two-hour interview. These semistructured life-history interviews examined how family members, primarily parents and close kin, supported sons in the transition into adulthood. The semistructured format provided a general guide for the questions that interviewers asked while allowing them flexibility to further explore aspects of participant's experiences in taking on adult-like responsibilities as children and adolescents (Daly, 2007). We asked participants to discuss their daily routines, next steps for work and education, support networks of friends and family, school and job experiences, what it meant to be an adult, and when their families first considered them to be adults. In many interviews, we also discussed family conflict (such as divorce or domestic violence), immigration and fluid residential or custodial change, coming to terms with masculinity and manhood, intimate relationships, incarceration and gang 
activity, and depression or related trauma. We should note that we never asked explicitly about the young men playing the role of man of the house; this term was used by participants to illustrate their personal understanding of the range of adult responsibilities that they assumed at a young age.

We also used a range of methods to enhance the trustworthiness of data (Lincoln \& Guba, 1985). Credibility and dependability of the data were enhanced by use of multiple sources of data and multiple methods of data collection, as well as prolonged engagement in the field. In-person discussions with the majority of the young men some weeks after their interviews (i.e., member checks) were used to check our understanding of how their experiences as adolescents in their families shaped their own views and expectations of being adults. Interviews were recorded on audiotapes and transcribed, and interview and field note texts were coded using AtlasTI software. Pseudonyms were used for participants.

Data Analysis. Following grounded theory, analysis occurs over three phases of coding: open, axial, and selective (LaRossa, 2005). Open coding, the first phase of analysis, refers to a "line-by-line" breakdown of the interview data (Daly, 2007). The researchers developed a set of sensitizing concepts from existing studies of disadvantaged young men and emerging adulthood, including adultification (and its dimensions), generativity, turning points, cool pose, coping strategies, socialization, soft skills, micro aggressions, and aspirations/expectations. We also began to discover emergent codes based on themes described by young men. These included the process of ghosting, or disappearing from school, work, family, and friends for set periods of time, and man of the house, as we discuss in this analysis.

Axial coding involved identifying conceptually similar categories while noting the overlapping and distinguishing characteristics of the codes. Working across 41 cases, we explored variation in specific codes. For example, participants were initially given the title man of the house after a range of specific events, such as departure of their fathers, their mothers' loss of a job, or bringing home money for the first time. We examined differences across each site, and by cultural context. Moreover, we found that some parents stepped back to let their sons perform adult duties; others carefully extended these duties step by step; and a few never asked their sons to take on accelerated responsibilities in care or provision. Finally, during a wave of selective coding, we conceptually linked together major and minor codes to offer a full and detailed framework of how being a man of the house shaped perceptions and even decisions about the transition into adulthood. This coding required following several cases throughout the analysis as well as summarizing three broad themes that reflected differences both within individual men's experiences and across them as groups. 


\section{Findings}

Among the young men in the youth development programs, the large majority had experienced forms of accelerated adulthood as boys and adolescents. Almost three quarters $(n=30,73 \%)$ of the men noted that they acted "like an adult" by contributing financially, caring for family members, or confronting challenges that required higher levels of maturity, including violence, substance use, or extensive self-care. Only 11 of the young men ( $27 \%$ of the group) stated that their parents had worked to take them step by step into adult responsibilities, in line with their age and maturity.

Not all of the 30 young men who encountered adult-like challenges would be considered men of the house, however. Seven of these young men spent extensive time alone as adolescents, without parental supervision and without responsibility for anyone but themselves. Over half of the entire sample ( $n=23,56 \%)$ were considered men of the house, indicated through direct reference during interviews or through interpretation by coders of the interview data.

For an adolescent or even a boy, a man of the house assumed responsibilities for family members, which could include his mother, father, siblings, cousins, or close kin. He may find a job and bring money home; he may cook dinner and dress younger children; he may supervise his siblings for days at a time, in the absence of older adults. A critical window onto the role of being man of the house was each young man's relationship with his mother. For some, man of the house was a role conferred by his single mother, in need of a partner for financial, caregiving, or even emotional support. Some adolescents took on this role despite disagreements and conflict with their mothers.

In the following sections, we explore three themes that emerged in our analyses. First, there were a range of clear family transitions that initiated boys and adolescents into early adult responsibilities. Second, as they struggled to fulfill expectations as men of the house, these young men faced a cluster of contradictions, confusion, and risks to their own health and wellbeing. Finally, they interpreted next steps into adulthood through their understanding of "being adults already," as one respondent explained. Often they noticed how vague responsibilities they had assumed as boys or early adolescents seldom translated well in adulthood, when they were called to earn money to support themselves or to care for their own children.

Early Family Transitions Initiate Young Men Into Adult Responsibilities. During times of stressful transitions during their childhood or early adolescence, participants discovered that their families needed extra help, substitute supervision, and a handful of additional resources to bolster limited dollars at the end of the week. Men noted that during these transitions, family turned to them, or alternatively, responsibilities seemed to fall into their laps. Such transitions often did not unfold quickly, but took many months to play out in family routines. One 
young man, Empire, insisted that "I'm gonna be one wise person when I get older." He insisted that he learned to "block out the periphery," to deal with stress and confusion in his life, because "I was raised with old people, I was raised sitting there listening to things that I'm not supposed to be listening to."

The departure of their own fathers from the household, or their inadequate fulfillment of the provider role, often became the presumption that the next-oldest male-whatever his age-might take on the title of man of the house. Whereas some participants were thrust into the role suddenly after fathers departed abruptly (i.e., due to death, dissolution of the couple relationship), others began enacting the role more gradually while their fathers were present but not contributing fully.

Fry was a young unemployed man in East Baltimore who realized on his own, at an early age, that his father was not living up to his family responsibilities. Although his father lived at home and even went to work, an unspoken assumption-and a growing notion in his own understandingwas that something was missing:

He was the type that he really do for himself, he'll steal from his own family, his sisters and stuff like that. It's like he really don't care, like he's in it for himself. I just started realizing when I was, like, 11 or 12 , damn, he ain't really doing nothing. I see why we keep having to move from here to here, there to here. See, when you young, you looking at it like, "well, daddy, he get up and go to work everyday" but you not knowing what is going on under the table. He get up and go to work everyday but he not bringing no money home whatsoever. He not putting no food in the house.

At this age, Fry began to look for odd jobs to pay for food for his siblings and himself. He had very limited understanding of the lack of work opportunities for adult men in the city, or the experiences that led his own father to disengage and to sink into depression. But his own entry into adulthood was closely linked to the failure of his own father to be a responsible adult. Similarly, Sylvester, an 18-year-old young man who dropped out of his high school in Baltimore, asserted that he became an adult, a man of the house, "when my father left." He could not recall when the departure happened; to him, he had been man of the house, "like, forever, as long as I can remember."

Relationships between mothers and their sons were deeply affected by the need for a man of the house. Single mothers looked to their sons for input about household decisions, as confidantes and protectors. And young men's relationships with their mothers often were transformed simply by witnessing hardship and conflict. For example, Matt, a 20-year-old father of two children, had served multiple sentences and had survived multiple injuries, including trauma from many years of gang activity. As a boy, he watched his father and mother fight hand to hand. "My mother left my 
father; I didn't care," he said. "That ain't nothing. I see that every day for real so that ain't bother me." He spent a handful of years as a boy, working alongside his mother to keep their household intact, but by the age of 15 he had left home and fathered his own child.

The young men occupied a position of authority while their mothers were away from the home but reverted to a more deferential position when mothers were present. Typically, they became the "adult" in charge of younger children when their mothers worked. However, their roles might deepen considerably when mothers hit rough patches in their own employment. De'Onte, a 17-year-old young man, was the youngest of three children, with two older sisters. He watched his best friend get shot and killed at the age of 4, "and I would just cry and walk in the house or go to sleep because of what I saw that day." He never knew his father, but he did remember "living with nothing... no TV, not eating meat for a whole year. That was amazing-how could I survive without meat?" De'Onte's mother was fired from her job at the post office, and his family lived off of unemployment and social security benefits. At the age of nine, he reassured her, "Mommy, we're getting out of [the projects], don't worry... alright, I'm gonna find a job."

Some men assumed responsibilities for their family members despite their mothers' resistance to their newfound authority. A young Salvadoran high school graduate, Emani, definitely was not a partner with his mother in household management. He reminded her of his biological father, a Guatemalan laborer who left her prior to Emani's birth. To him, years of resentment had created a tolerance of his presence, but little closeness to his mother. However, at six years old, he confronted his mother's brother, who attempted to assault Emani's sister:

I tried to stop him and stuff, but I wasn't strong enough. He overpowered me, beat me down pretty hard, but we got him arrested.... And then my family went mad, they all ended up chipping in to put bail for him. So that's why I always, you know, I wasn't very close to them.

Although he kept his distance from adults in his family, Emani threw himself into caring for his sisters and cousins. He was known, it seemed, as the emotional center of his family and his group of peers.

Some young men discussed a long history of living apart from their families, of growing up "on my own." Mike was a 23 year old who was kicked out of school the last few weeks of his senior year, after he and his girlfriend got into trouble in the neighborhood. His father had died when Mike was 15, and his mother passed away when he was 21 . At the time of our interview, he had started a temporary job at Target, but had been kicked out of his aunt's apartment. Mike had little to say about being a man of the house; he recalled few days in his family home and had few opportunities to try out adult responsibilities. 
Finally, as we discussed above, about a quarter of the entire group of participants lived with their parents who worked diligently to scaffold experiences in ways that were appropriate for their age and maturity. Although they grew up in the same neighborhoods and schools as other participants, these young men did not deal with inappropriate adult responsibilities or confusing knowledge about conflict or relationships. Eugene was a 19-yearold high school graduate at the Diversity Matters program, and he discussed working with his father on his first job at 13 years old. His family formed a supportive "Team Gene, so I'm happy," and by his account, they had high expectations for him as a middle child because they knew he could succeed. Although he dropped out of high school in tenth grade, Kuron, a 17 year old in the UP program, lived with both of his parents. They stuck by him to study and earn his GED, and he looked forward to doing more things as a family, "like when we used to go to church." These young men's experiences seemed in marked contrast to the rush of responsibilities that many of their peers had to absorb on a daily basis.

Contradictory Expectations Place Risks on Men of the House. Participants assumed adult responsibilities at different ages, and families' expectations expanded as they matured, gained greater capacities, and access to resources. But as boys and early adolescents, they encountered contradictory expectations from their families, communities, and larger society. Although being men of the house could train them for self-sufficiency and socialize them to successful adulthood, it was more likely to overwhelm these young men who could become confused and put their own health and well-being at risk trying to live up to accelerated expectations.

In the absence of their mothers or other adults, many boys and adolescents were asked to manage households. They allocated space to siblings, took charge of cleaning, and delegated household tasks to other family members. These management tasks could prove difficult in small apartments with few resources, but their roles were vital to keeping families fed and on-task. As Sylvester discussed his experiences managing household resources above, he noted that he "had to go around the house and clean up." He even made the executive decision to move out of his room- "to throw the bed out and everything" - that he shared with his sister, as a sacrifice to make room for his niece, who needed a place to stay. For Sylvester, the distinctions between managing his household, taking care of younger children, and protecting them were unclear. Such responsibilities merged and resurfaced depending on what was needed on a particular day. Similarly, for Justin, a young man in East Baltimore, caretaking involved not only checking in on his siblings, but soon his mother's well-being as well. His mental checklist was as extensive as many parents' checklists:

[And what was your role in the family? Did you have responsibilities when you were 11 or 12?] Psssh... um ... being the man of the house and keeping my brothers and sisters in order, help moms out. [When you say man of the 
house, how did you do that?] Make sure the house is cleaned up, make sure they're in bed in time. You know, food get cooked, help served the plates and everything. Help out with the homework and everything. You know, make sure the trash is took out, floor is mopped and swept. Bathrooms and all of that, make sure the door is locked. Make sure everybody has their night clothes. And you know, make sure my work was done and make sure moms is good and get up the next morning and go to school. Checked on her, you know, ask her how her day was... do you need anything before I go to bed and stuff like that.

Young men allocated their own time, space, and limited resources to meet the needs of other members of their families, even if that means personal sacrifice. In addition to managing household resources, they often provided financially for their families, even at very young ages. De'Onte, in his pledge to move his mother out of the projects, began to play music at church at nine years old. He brought home his first paycheck of $\$ 500$, and he came home in tears-and his mother sat and cried as well. From that moment, "we've been moving on up!" as partners who shared responsibility for their family's well-being. He also washed clothes, cooked, cleaned, and did yard work ("now that we have a back yard"). Although this was an exceptional circumstance, many young men discussed bringing home money when they could find occasional hours as day laborers that paid cash-in-hand.

While some young men were able to earn money through formal employment, their relative youth limited mainstream job opportunities. As an alternative, young men turned to engagement in illegal activities. Fry began selling drugs to provide for his family when his father failed to do so. Although their families needed their financial contributions, Fry's story illustrates that young men may pay the heavy price of incarceration, injury, or death as they aim to help their families:

[I] was the so-called provider in my family because I seen that my father wasn't doing it. So, I felt like because I was the next man in line and I was home, it was my job to be. That's really made me want to get out there and want to sell drugs and want to hustle. And that's really got me in a position to get locked up and my little brother says like, we need clothes, shoes, all that.... That's responsibility.

To complicate his role as man of the house, Fry's commitment to earn money placed his mother in a difficult situation. She knew that he brought home "dirty money," and she argued that "it ain't good money if it's dirty money, even though the money was helping her." He asserted that he was being a man, placing responsibility for his family in front of all elsealthough Fry's mother was torn by placing her son at great risk: 
She had no other choice because she understood where I was coming from. I was basically trying to be a man before I had to. There was no other alternative unless you want to be sitting out on the streets and that's not what we wanted. I wasn't really trying to hear her because my main focus was providing for my family. I mean a lot of my life experience came from me worrying about the next person. Well, I can't say the next person because they not just anybody. I was worrying about my family.

Men who were committed to earning money-and could do so-were tough to find in these neighborhoods, and some found that their family commitments could multiply quickly, even at a young age. Matt had split bills with his mother when he was 15, and "she didn't want me doing that." Like Fry, he pushed past his mother's resistance and stressed to her that "she couldn't be mad at me because all of my kids were taken care of, she was taken care of, her bill was taken care of, I was taken care of." His ability to pay for her daily expenses, as well as himself and his young son's needs, is an impressive accomplishment for an adolescent. In effect, Matt was a man of the house twice over, although hustling eventually led to his arrest and took him out of these homes-leaving his infant son and his own mother at even greater risk.

Further, some young men were abruptly pushed out of their roles as man of the house by the entry of older males into their lives. After serving as a pseudopartner for their single mothers for years during adolescence, they were stunned to find their mothers' boyfriends move into their homes and challenge their hard-won authority. These older men forced the young men to renegotiate their management tasks or their ability to make decisions about cooking, cleaning, and care. Emani, for example, was pulled into numerous fist fights with his stepfather, who insisted that "there isn't any room for another man in this house" and tried his best to move the young man out of the house when he turned 18. Apart from losing respect and authority, relationships with their mothers became much more tenuous. They were no longer junior partners with the presence of actual (or potential) household partners, and the companionship that they shared with their mothers-although it may have been developmentally questionable at times-often dissolved in the transition into adulthood as a result.

Difficult Transition Into Adulthood Is a Consequence of Adultification. When we discussed how they felt about being an adult—or if they considered themselves to be adults-participants had clear opinions, but often unsettled identities. Their confrontations with challenges such as family conflict, violence, or emotional concerns that would burden adults many times their own age seemed to shape how they saw themselves. In part, the disjuncture between accelerated adulthood status as men of the house, and the inability to move toward successful adulthood status as self-sufficient workers and family men, was jarring. 
Kevin, a 19-year-old African American GED student, lived with his father and struggled to simply take care of his own needs:

I became an adult when I started working with my father, two years ago. I used to buy my own food, buy my own clothes, pay my phone bill. You're gonna play the Grown Ass Man however you want to pay. And if you like my age, like eighteen, or if you're sixteen, and you take care of yourself then you one of them.

Sylvester, who felt that he'd been an adult "forever," faced the complications of becoming a man and how he almost fooled himself into believing that he would not have to prove himself repeatedly, and in challenging ways, as he aged:

I always said I'm an old man because I got respect, ever since I grew up, I always did the right thing... I call myself a fool now, but, cause I preach to my friends now, they say always preaching cause I try to get people on the right track. I'd do for somebody before I do myself, you feel me, try to help somebody else before I help myself. But when I got older it was like I wanted for myself, but at the same time I got to for the family as well, so that's when I start trying to go out, without no jobs, trying to get my own money. Now it's like, eighteen now, and them books aren't for everybody, you feel me.

The realities of getting a college degree or finding a good job proved daunting to Sylvester, as to many young men in disadvantaged communities. As benchmarks of successful adulthood, they seemed unattainable, and starkly separated from the experiences of adolescence that had seemingly prepared them to step up as adults. Why couldn't they take care of themselves after they had taken care of other family members when they were so young?

In the face of the barriers to school and work, families encouraged young men to at least put on the appearance of being responsible and engaged with making progress. Snoop, a 17-year-old high school dropout, acknowledged the importance of public perception as he moved into adulthood:

My peoples want to see you doing good, they want to see you like you got to have your shit looking good. You gotta be basically a clean cut dude, can't be no raggedy dude. You can be a man and still be like raggedy for real but you still you know got your priorities straight. They just want to see you feeling better about yourself for real, they want to see you step your level up a little bit, you got a good paying job and you go to school and start looking good. They want you to be a good role model to any other young man or woman in our family. 
Although these expectations seemed basic enough, they were quite daunting for young men. Few men in their own families had achieved stability as role models, and it was risky for young men to make moves toward successful adult achievements for fear of failure.

These young men realized that they could not achieve adulthood on their own, and many turned repeatedly to their own parents for help in the transition. In doing so, they faced up to generations of loss and pain in job loss, broken relationships, or strained relationships with parents. At 17, Stefan had a two-year-old son who was moved to Georgia, but he was committed to earning his GED after leaving school in eighth grade. He lived with his father, which set him apart from the large majority of young men in these two programs. Stefan had to convince his father, as well as himself, that he was ready to become an adult:

\begin{abstract}
How am I going to make my own decisions, if I'm always depend on my father? Well I've been at that stage for a while. But I've tried to keep a lot of it in. But now as I'm getting older it's starting to come out more. My father's start to see it but he's taking it the wrong way. He's taking it as disrespect when it's not disrespect it's just me wanting to choose thing for myself, wanting to do things on my own. Now, he's, uhh, recently, he's finally just listened to me. I didn't let him have it but I said, "Listen I'm not disrespected you I'm just getting older." I said, "I know your father passed away and you never had that time to grow out from under your father's shell. How every guy's gotta grow out from under his father, I'm here to show you how it looks. I'm not here to disrespect you dad, but I'm showing you now."
\end{abstract}

For those with limited support from and no regular contact with family members, early experiences of adultification could lead young men to isolate themselves from family and friends. They could not commit to exploring work and school until they examined who they might become as adults in a society with few spaces for them. They "ghosted" through daily routines that did not put them "at risk" while at the same time "being a risk" to family and friends. Emani still did not know "what comes next." He lived a few nights each week with his mother and stepfather, but left the house when his mother woke up for work. Other nights he spent sleeping outside or on a friend's couch. Joseph, a young mentor in the Diversity Matters program, also couch-surfed among three different residences, unable to tell us where he might spend the next night. He had not spoken with his parents in many months, and at 18 years old, he had entered into a "gray period" to do "a lot of thinking about what comes next." At 20, Matt looked back on the birth of his two children, his incarceration and physical injuries, and how his efforts to provide and care had led him to be wary of trusting friends or family: 
I don't trust anyone. I ain't getting into trouble, not going to jail, none of that. Having a child gave me a humbleness and all that. Don't have new freedoms as an adult. I was living like an adult as a kid.

In contrast, the small number of young men who did not experience adultification could also point to efforts that their families might make to scaffold a series of next steps into actual adulthood. On working-class wages, without their own college or high school education, their parents sacrificed and hoped each day that their sons could move past the years of risk that young adulthood promised. Brandon, an 18-year-old Salvadoran mentor outside of Washington, DC, aspired to own a restaurant. He worked hard as a busboy and landed three different jobs that kept him working 30 hours on top of his high school schedule. He laughed as he recounted his parents' efforts to urge him toward adulthood:

I don't want to be called old. My parents would call me a young man. Does that count? Like she tells me "you can sometimes make like your own decisions and choices now so you need to be careful out in this world now." I guess, she'll consider me pretty much an adult once I graduate in June. So she knows I'll make the right decision, cause I've been doing it for a while. Bit by bit they're starting to pull back now. Like, well, with the whole job thing, the fact that I got the job is because they want me to use my own money to get what I want instead of me asking them all the time "get me this, get me that." And they want me to understand that, you need to earn it, so I feel comfortable with that.

\section{Discussion}

In communities of economically disadvantaged families, the transition into adulthood becomes a process of life course negotiation for young men who struggle to fit into settings that have only limited places for them as adults. First, we found that boys and early adolescents were recruited into the role of man of the house during critical family turning points. These included the departure of their fathers from their households, or their fathers' failures as providers; the movement of their mothers to full-time employment, or the loss of such a job; depression, stress, or other mental health concerns for their parents; or even the addition of multiple younger siblings or related kin, who overwhelmed caregiving capacity for adults in their families.

Second, in the rush to encourage these boys and adolescents to become men of the house, expectations for care and provision were often vague, confusing, and contradictory. For example, many were expected to manage households with little money or social support, which were tasks that would thwart most grown adults. In turn, men of the house sought and usually failed to find substantial resources through mainstream activities-like a 
full-time job. Many turned to activities like hustling that presented risks to their own health and well-being.

Finally, they interpreted next steps into adulthood through their understanding of "being adults already," as one respondent explained. Being adultified resulted in a confusing and complicated transition into actual adulthood. Often they noticed how responsibilities they had assumed as boys or early adolescents seldom translated well into adulthood. Being selfsufficient at 21 was quite different from contributing cash to the household at 13; solo caregiving for siblings for a handful of hours paled in comparison to daily involvement with one's children.

These findings echo prior research which finds that pseudomaturity or real maturity depends largely on family and community contexts (Galambos, Kolaric, Sears, \& Maggs, 1999), not simply on individual traits or subjective perceptions. It is an in-depth understanding of these social contexts that offer a glimpse of the underlying mechanisms that sustain the impact of adultification. The urgent needs of families living in poverty may exacerbate the experience of adultification. And complicated and fluid family relationships, in which boys and adolescents step in for their fathers or step out as mothers' partners contest their accelerated authority, may further solidify the importance of being an adult. Poverty and family relationships as well as the timing of adultification each shape an emergent sense of self for boys and early adolescents. They carry this sense of self, this adult identity, ahead for many years, well into their own transition into adulthood.

In addition to identifying problems for disconnected young adults, we need to identify processes that foster connections to adult roles. Social support can be critical for children and adolescents, and we assume that it is also critical for successful transition into adult roles. But research is limited about the processes and contexts of such support. Moreover, economically disadvantaged men of color have been marginalized by policies that regulate their presence in dynamic and complex family households for decades (Cross-Barnet, Cherlin, \& Burton, 2011; Lefkowitz, 2011).

Taking into account the early life experiences of young men as they step up to take on adult-like responsibilities, social policy and programs might offer clear and systemic pathways into school and work for disadvantaged youth (Edelman, Holzer, \& Offner, 2006; Mincy, 2006). Further, sustained efforts to redress poverty and inequality in general will potentially relieve young children of the burdens they now assume to support their own families, with the payoff seen years later, in their substantial achievements as adults.

Research support provided by the William T. Grant Foundation.

\section{References}

Burton, L. (2007). Childhood adultification in economically disadvantaged families: A conceptual model. Family Relations, 56, 329-354. 
Burton, L., \& Stack, C. (2014). "Breakfast at Elmo's": Adolescent boys, slow ethnography, and disruptive politics in the kinscripts' narrative. In M. Nelson, A. Garey, \& R. Hertz (Eds.), Open to disruption: Time and craft in the practice of slow sociology. Nashville, TN: Vanderbilt University Press.

Burton, L., Winn, D., Stevenson, H., \& McKinney, M. (2014). Childhood adultification and the paradox of parenting: Perspectives on African American boys in economicallydisadvantaged families. In J. Arditti (Ed.), Family problems: Stress, risk, E resilience. New York, NY: Wiley Blackwell.

Coltrane, S. (1997). Family man: Fatherhood, housework, and gender equity. New York, NY: Oxford University Press.

Cross-Barnet, C., Cherlin, A., \& Burton, L. (2011). Bound by children: Intermittent cohabitation and living together apart. Family Relations, 60, 633-647.

Daly, K. (2007). Qualitative methods for family studies and human development. Thousand Oaks, CA: Sage.

Edelman, P., Holzer, H., \& Offner, P. (2006). Reconnecting disadvantaged young men. Washington, DC: Urban Institute Press.

Foster, H., Hagan, J., \& Brooks-Gunn, J. (2008). Growing up fast: Stress exposure and subjective "weathering" in emerging adulthood. Journal of Health and Social Behavior, 49, 162-177.

Furstenberg, F., \& Hughes, M. (1995). Social capital and successful development among at-risk youth. Journal of Marriage and Family, 57, 580-592.

Galambos, N., Kolaric, G., Sears, H., \& Maggs, J. (1999). Adolescents' subjective age: An indicator of perceived maturity. Journal of Research on Adolescence, 9, 309-337.

Geronimus, A. (1992). The weathering hypothesis and the health of African-American women and infants: Evidence and speculations. Ethnicity \& Disease, 2, 207-221.

Geronimus, A. (2001). Understanding and eliminating racial inequalities in women's health in the United States: The role of the weathering conceptual framework. Journal of the American Medical Women's Association, 56, 133-136, 149-150.

Harding, D. (2010). Living the drama: Community, conflict, and culture among inner-city boys. Chicago, IL: University of Chicago Press.

Johnson, M. K., \& Mollborn, S. (2009). Growing up faster, feeling older: Hardship in childhood and adolescence. Social Psychology Quarterly, 72, 39-60.

LaRossa, R. (2005). Grounded theory methods and qualitative family research. Journal of Marriage and Family, 67, 837-857.

Lefkowitz, A. (2011). Men in the house: Race, welfare, and the regulation of men's sexuality in the United States, 1961-1972. Journal of the History of Sexuality, 20, 594-614.

Lincoln, Y., \& Guba, E. (1985). Naturalistic inquiry. Thousand Oaks, CA: Sage.

Marsiglio, W., \& Roy, K. (2012). Nurturing dads: Social initiatives for contemporary fatherhood. ASA Rose Series. New York, NY: Russell Sage Foundation.

Mincy, R. (Ed.). (2006). Black males left behind. Washington, DC: Urban Institute Press.

Mouw, T. (2005). Sequences of early adult transitions: A look at variability and consequences. In R. A. Settersten, Jr., F. F. Furstenberg, Jr., \& R. G. Rumbaut (Eds.), On the frontier of adulthood: Theory, research, and public policy (pp. 256-291). Chicago, IL: University of Chicago Press.

Rich, J. (2009). Wrong place, wrong time: Trauma and violence in the lives of young Black men. Baltimore, MD: Johns Hopkins University Press.

Roy, K., \& Burton, L. (2007). Mothering through recruitment: Kinscription of nonresidential fathers and father figures in low-income families. Family Relations, 56, 2439.

Roy, K., Dyson, O., \& Jackson, J. (2010). Intergenerational support and reciprocity between low-income African American fathers and their aging mothers. In W. Johnson \& E. Johnson (Eds.), Social work with African American males (pp. 42-60). New York, NY: Oxford University Press. 
Roy, K., \& Smith, J. (2012). Nonresident fathers and intergenerational parenting in kin networks. In N. Cabrera \& C. Tamis-LeMonda (Eds.), Handbook of father involvement: Multidisciplinary perspectives (2nd ed., pp. 320-337). New York, NY: Routledge.

Roy, K., \& Vesely, C. (2009). Caring for "the family's child": Social capital and kin networks of young low-income African American fathers. In R. Coles \& C. Green (Eds.), The myth of the missing Black father (pp. 215-240). New York, NY: Columbia University Press.

Roy, K., Vesely, C., Fitzgerald, M., \& Buckmiller Jones, N. (2010). Young fathers at work: The influence of parental closeness and contact on employment. Research on Human Development, 7, 123-139.

Shanahan, M., Porfeli, E., Mortimer, J., \& Erickson, L. (2005). Subjective age identity and the transition to adulthood. In R. Settersten, F. Furstenberg, \& R. Rumbaut (Eds.), On the frontier of adulthood: Theory, research, and public policy (pp. 225-255). Chicago, IL: University of Chicago Press.

Thornton, A., Alwin, D., \& Camburn, D. (1983). Causes and consequences of sex role attitudes and attitude change. American Sociological Review, 48, 211-227.

Way, N. (2011). Deep secrets: Boys' friendships and the crisis of connection. Cambridge, MA: Harvard University Press.

Weiss, R. (1979). Growing up a little faster: The experience of growing up in a single parent household. Journal of Social Issues, 35, 97-111.

Young, A. (2004). The minds of marginalized Black men: Making sense of mobility, opportunity, and future life chances. Princeton, NJ: Princeton University Press.

KEVIN ROY is an associate professor in the Department of Family Science, School of Public Health at the University of Maryland, College Park. E-mail: kroy@umd.edu, webpage: http://www.sph.umd.edu/fmsc/people/fac /kroy.html

LAUREN MESSINA is a doctoral student in the Department of Family Science at the University of Maryland. E-mail: lauren.messina@gmail.com

JoCELYN SMith is the Paul B. Cornely Postdoctoral Scholar and Research Fellow at the University of Michigan. E-mail: jrsmith11@gmail.com

DAMIAN WATERS is a doctoral student in the Department of Family Science at the University of Maryland. E-mail: dmw23georgetown@gmail.com 